\title{
Study on the Spontaneous Imbibition Characteristics of the Deep Longmaxi Formation Shales of the Southern Sichuan Basin, China
}

\author{
Chao Qian $\mathbb{D},{ }^{1,2}$ Xizhe Li, ${ }^{1}$ Weijun Shen $\mathbb{D},{ }^{2,3}$ Wei Guo, ${ }^{1}$ Yong $\mathrm{Hu}^{1}$ and Zhongcheng $\mathrm{Li}^{4}$ \\ ${ }^{1}$ Research Institute of Petroleum Exploration and Development, PetroChina, Beijing 100083, China \\ ${ }^{2}$ Key Laboratory for Mechanics in Fluid Solid Coupling Systems, Institute of Mechanics, Chinese Academy of Sciences, \\ Beijing 100190, China \\ ${ }^{3}$ School of Engineering Science, University of Chinese Academy of Sciences, Beijing 100049, China \\ ${ }^{4}$ Exploration and Development Research Institute, PetroChina Jilin Oilfield Company, Songyuan 138000, China
}

Correspondence should be addressed to Weijun Shen; wjshen763@imech.ac.cn

Received 24 June 2021; Revised 31 August 2021; Accepted 11 September 2021; Published 14 October 2021

Academic Editor: Afshin Davarpanah

Copyright (c) 2021 Chao Qian et al. This is an open access article distributed under the Creative Commons Attribution License, which permits unrestricted use, distribution, and reproduction in any medium, provided the original work is properly cited.

\begin{abstract}
Deep shale gas reservoirs are a significant alternative type of shale gas reservoir in China. The productivity of deep shale gas wells is lower than that of shallow shale, and the imbibition characteristics of deep shale have a significant effect on the retention and backflow of fracturing fluid and the productivity of shale gas wells. In this study, the pore structure characteristics of organic-rich deep shale in the Lower Silurian Longmaxi Formation of Weiyuan-Luzhou play were analyzed by low-temperature nitrogen adsorption experiments, and then the imbibition characteristics and factors influencing deep shale were extensively investigated by spontaneous imbibition and nuclear magnetic resonance experiments. The results show that mainly micropores and mesopores are growing in the deep organic-rich shale of the Longmaxi Formation. The spontaneous imbibition curve of deep shale can be divided into an initial spontaneous imbibition stage, an intermediate transition stage, and a later diffusion stage, and the imbibition capacity coefficient of deep shale is lower than that of shallow shale. The transverse relaxation time (T2) spectrum distributions suggest that clay hydration and swelling produce new pores and microcracks, but then some pores and microfractures close. Deep shale reservoirs have an optimal hydration time when their physical properties are optimal. The increasing pore volume and the decreasing TOC content can enhance the imbibition capacity of shale. An inorganic salt solution, especially a $\mathrm{KCl}$ solution, has an inhibitory effect on the imbibition of shale. Higher salinity will result in a stronger inhibitory effect. It is crucial to determine the optimal amount of fracturing fluid and soaking time, and fracturing fluid with a high $\mathrm{K}^{+}$content can be injected into the Longmaxi Formation deep shale to suppress hydration. These results provide theoretical guiding significance for comprehending the spontaneous imbibition and pore structure evolution characteristics of deep shale and enhancing methane production in deep shale gas reservoirs.
\end{abstract}

\section{Introduction}

Shale gas resources in China are abundant, the proven accumulated shale gas reserves were $1.7865 \times 10^{12} \mathrm{~m}^{3}$ in China by the end of 2019, and shale gas production is expected to reach $5.0 \times 10^{10} \mathrm{~m}^{3}$ in 2030 [1]. There is no doubt that shale gas has become the most crucial component of Chinese natural gas production in recent decades. At present, the exploitation of shallow marine shale gas reservoirs (shallower than
$3500 \mathrm{~m}$ ) in China has achieved outstanding results. However, the production of shale gas wells has experienced a sharp decline in three years, and it is necessary to find new blocks and layers for production. Deep shale gas reservoirs (deeper than $3500 \mathrm{~m}$ ) account for more than $65 \%$ of the total resources and are a hotspot and alternative for shale gas research in China [2]. However, similar to deep shale gas reservoirs in North America, the gas production of deep shale gas wells in the Weiyuan, Fuling, and Fushun- 
Yongchuan blocks in China is relatively low after the fracturing $[3,4]$. The fracturing effect and production of shale gas wells are closely related to the retention, imbibition, and backflow of fracturing fluid.

Shale gas reservoirs are self-generated and self-stored, with tight reservoirs dominated by nanoscale pores and characterized by low porosity $(2 \% \sim 8 \%)$ and ultralow permeability (10 100 nD) [5]. Horizontal wells and multistage fracturing and large hydraulic fracturing technology efficiently improve the development of shale gas, and the pore capillary pressure after fracturing can reach several hundred MPa [6]. The capillary force drives the fracturing fluid into the shale reservoirs and causes retention, and the dry gas reservoir backflow rate is lower than that of water (oil) gas reservoirs $[7,8]$. A large amount of retained fracturing fluid in shale formations is imbibed by the surrounding shale matrix, microfractures, and other fracture networks through capillary forces, gravity, hydrogen bond forces, van der Waals forces, and hydration forces [9-11]. The hydration and swelling of clay result in lower formation permeability and shale reservoir water blockage, leading to a significant decrease in gas productivity. Some studies have indicated that the clay swelling caused by water-rock reactions in some shale reservoirs produces microfractures [12-14], which can lead to the removal of water blockages in shale reservoirs and an increase in gas well productivity [15]. Shale hydration characteristics are closely related to clay mineral composition, and Zeng et al. [16] reported that shale with a high illite content is not prone to hydration and thus has limited room for pore structure improvement. Shale with a high smectite content is prone to hydration and swelling and thus has a higher potential for pore structure improvement by stimulation.

In recent years, many studies have been conducted on the imbibition capacity of shale [17-19]. The imbibition capacity of shale is mainly related to the mineral content and pore structure, especially the content of smectite and illite/smectite mixed layer (I/S) minerals [17]. Gao et al. [18] found that the hydrophilic inorganic pores of shale with high clay content are well grown, while the oil-wet organic pores of organic-rich shale are well developed. Biogenic silica has strong compressive resistance, and samples rich in quartz are conducive to preserving the connected pores to promote the imbibition of water [20]. In addition, with increasing sample porosity and pore volume, the connectivity of the pore network improves [19]. The addition of surfactant can change the wettability of the shale surface to water and reduce the loss of fracturing fluid [21]. The salt solution could reduce the osmotic pressure of the clay semipermeable film, which would reduce the imbibition ability of shale. Ions in a salt solution $\left(\mathrm{Ca}^{2+}, \mathrm{Ba}^{2+}, \mathrm{CO}_{3}{ }^{2-}, \mathrm{SO}_{4}{ }^{2-}\right)$ may chemically interact with clay to block pores in certain pore size ranges, thereby reducing the spontaneous imbibition capacity of shale [22]. Zhou et al. [23] found that the influence of fracturing fluid composition largely depends on the clay content of shale. Zeng et al. [16] also announced that inorganic cations could inhibit the hydration and swelling of clay minerals and have a stronger inhibitory effect on illite expansion, especially $\mathrm{K}^{+}$. However, there are differences in mineral composition and pore structure between deep shale and shallow shale. Therefore, it is necessary to understand the spontaneous imbibition and pore structure evolution characteristics and influencing factors of deep shale to optimize the extraction conditions in shale gas reservoirs.

In this study, the petrophysical properties of deep shales from the lower Silurian Longmaxi Formation shales of the southern Sichuan Basin, China, were measured, and the spontaneous imbibition of deep shales was evaluated using low-field nuclear magnetic resonance and a high-precision electronic balance. The spontaneous imbibition characteristics of deep shale were analyzed, and the T2 spectral characteristics during shale imbibition were evaluated. Furthermore, the effects of mineral composition, TOC content, pore structure, and inorganic salt solution on imbibition characteristics were discussed.

\section{Materials and Methods}

The southern Sichuan Basin is located at the southwest margin of the Upper Yangtze Platform in southern China. The Lower Silurian Longmaxi Formation shale in the WeiyuanLuzhou area is buried at a depth of $3500 \sim 4500 \mathrm{~m}$. It was mainly deposited in the Early Silurian RhuddanianAeronian Age (439-444 Ma BP), which was in a shelf plain to shallow water shelf environment [24]. In this study, eight samples were selected from the Longmaxi Formation shale in well $\mathrm{W}$ and well $\mathrm{L}$ with a sampling depth of $3873 \sim 4041 \mathrm{~m}$. Sample sizes and other information are listed in Table 1 . The porosity of shale samples was measured by the fluid saturation method, and permeability was obtained by the pressure pulse decay method, and the above tests were performed at Analysis Experiment Center of Exploration and Development Research Institute of Petrochina Southwest Oil and Gasfield Company.

Some shale samples were crushed to powder, and then the mineral composition and total organic carbon content were tested by an XRD analyzer and carbon-sulfur analyzer. The Bruker D8 Advance Diffractometer has a scanning speed of $10^{\circ} / \mathrm{min}$ and a step width of $0.02^{\circ}$. Lowtemperature nitrogen adsorption experiments were carried out by using an automatic surface analyzer produced by micromeritics. The parameters of pore size distribution and specific surface area were calculated using the adsorption branch of low-temperature nitrogen curve data. Pore connectivity is determined by the pore structure characteristics of shale reservoirs and affects fluid migration in shale gas reservoirs. The pore size distribution and specific surface area of shale can be obtained by low-temperature nitrogen adsorption data, DFT models, and BET models [24-27].

The experimental process of shale sample spontaneous imbibition and nuclear magnetic resonance (NMR) is shown in Figure 1. Before the experiment, the shale plunger samples were dried at $65^{\circ} \mathrm{C}$ for 24 hours to remove moisture. First, the sample was soaked in salt solution. Second, it was taken out at regular intervals to remove the surface moisture, and then the wet weight of the sample was measured. Finally, the characteristics of fluid distribution in the pores of the core samples were obtained by using Newmark's low-field 
TABLE 1: Some measured properties of the deep Longmaxi Formation shales samples.

\begin{tabular}{lcccccc}
\hline No. & Depth $(\mathrm{m})$ & Diameter $(\mathrm{mm})$ & Height $(\mathrm{mm})$ & TOC $(\%)$ & Porosity $(\%)$ & Permeability $(\mathrm{mD})$ \\
\hline W1 & $3873.63-3873.71$ & 24.97 & 24.68 & 1.56 & 5.05 & 0.0000598 \\
W2 & $3873.92-3874.00$ & 24.76 & 16.50 & 1.08 & 7.12 & 0.0004471 \\
W3 & $3882.12-3882.19$ & 24.76 & 24.58 & 4.50 & 7.25 & 0.0000077 \\
W5 & $3886.99-3887.13$ & 25.28 & 21.19 & 3.37 & 5.60 & 0.0001923 \\
L6 & $4014.87-4014.96$ & 24.76 & 27.92 & 2.49 & 3.15 & 0.0002595 \\
L8 & $4020.38-4020.60$ & 24.8 & 56.07 & 2.76 & 5.26 & 0.0000998 \\
L9 & $4026.12-4026.23$ & 25.3 & 23.45 & 3.98 & 6.25 & 0.0001979 \\
L10 & $4031.23-4031.44$ & 24.4 & 45.54 & 5.28 & 5.65 & 0.0001667 \\
\hline
\end{tabular}

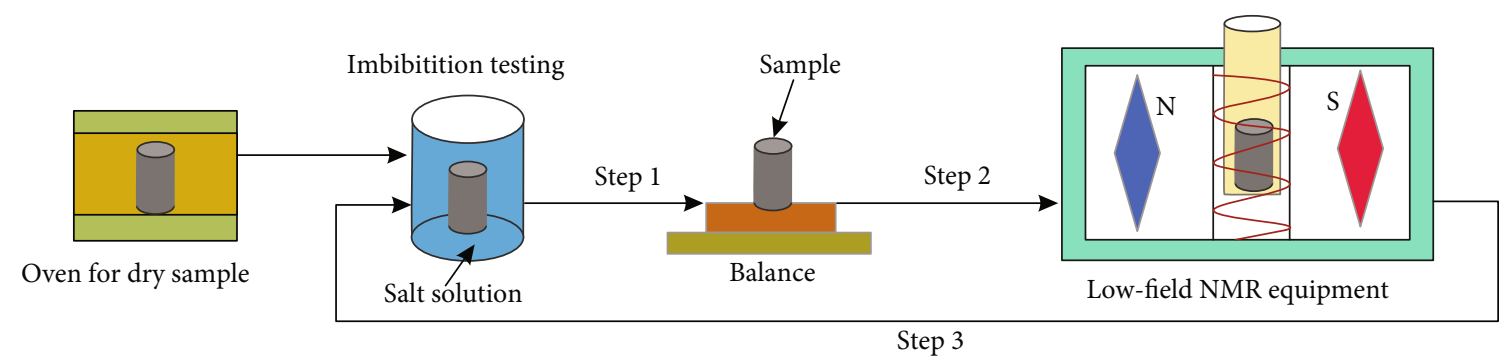

FIGURE 1: The experimental process of shale sample spontaneous imbibition and NMR.

TABLE 2: Spontaneous imbibition curve parameters of the deep Longmaxi Formation shale samples.

\begin{tabular}{|c|c|c|c|c|c|}
\hline Sample number & Solution & Stage I slope & Stage II slope & Stage III slope & Peak value \\
\hline W1 & \multirow{8}{*}{$\mathrm{NaCl}: \mathrm{Cl}^{-}$of $15,000 \mathrm{mg} / \mathrm{L}$} & 0.0651 & 0.0056 & 0.000373 & 0.0499 \\
\hline W2 & & 0.0601 & 0.0031 & 0.000412 & 0.0580 \\
\hline W3 & & 0.0801 & 0.0021 & 0.000633 & 0.0674 \\
\hline W5 & & 0.0456 & 0.0029 & 0.000367 & 0.0629 \\
\hline L6 & & 0.0825 & 0.0026 & 0.000681 & 0.0486 \\
\hline L8 & & 0.0538 & 0.0041 & 0.000137 & 0.0356 \\
\hline L9 & & 0.0346 & 0.0059 & 0.000624 & 0.0588 \\
\hline L10 & & 0.0298 & 0.0094 & 0.0051 & 0.0511 \\
\hline
\end{tabular}

nuclear magnetic resonance equipment. Step 3, step 1, and step 2 were processed in circulation until the sample mass remained unchanged. The size of the experimental shale samples is listed in Table 1. To prevent the samples from splitting seriously, $\mathrm{NaCl}$ solution with a salinity of $\mathrm{Cl}^{-}$of $15,000 \mathrm{mg} / \mathrm{L}$ listed in Table 2, such as the salinity of formation water, was selected to study the effect of sample mineral composition and pore structure on the imbibition characteristics. Meanwhile, to investigate the effect of inorganic salt solution on imbibition characteristics, L10 samples were subjected to spontaneous imbibition experiments with salt solutions containing different salts and with different salinities, as listed in Table 3. The instrument model was MiniMR-VTP, and the CPMG pulse sequence was used to acquire the signal several times. The parameters of the CPMG sequence include echo time interval (TE), waiting time (TW), echo number (NE), and repeated sampling number (NS). To reflect the characteristics of the shale micro/nanopore structure as much as possible, the parameter settings were as follows: $\mathrm{TE}=0.07 \mathrm{~ms}, \mathrm{TW}=2500 \mathrm{~ms}, \mathrm{NE}=2000$, and NS $=16$. To facilitate the comparative analysis, the above parameters were set in the follow-up test.

\section{Theory}

A large number of investigations have been conducted on the characteristics and evaluation methods of spontaneous imbibition. Lucas [28] and Washburn [29] derived a linear relationship between the invasion height of the fluid in capillaries with equal cross-sections and the square root of time when gravity and inertia were ignored. The model is usually called the LW equation. Tight shale reservoirs are dominated by nanoscale pores, and spontaneous imbibition is a process in which the nonwetting phase replaces the wet phase. Suction is mainly a capillary force, and gravity is often negligible. The function equation for the spontaneous imbibition volume and time in homogeneous porous media was obtained by Handy [30]. For the porous media with good 
TABLE 3: Parameters of imbibition curves of the deep shale samples in different salt solutions.

\begin{tabular}{cccccc}
\hline No. & Solution & Stage I slope & Stage II slope & Stage III slope & Peak value \\
\hline \multirow{3}{*}{ L10 } & $\mathrm{NaCl}: \mathrm{Cl}^{-}$of $15,000 \mathrm{mg} / \mathrm{L}$ & 0.0298 & 0.0094 & 0.0051 & 0.0511 \\
& $\mathrm{KCl}: \mathrm{Cl}^{-}$of $15,000 \mathrm{mg} / \mathrm{L}$ & 0.0230 & 0.0049 & 0.0021 & 0.03315 \\
& $\mathrm{NaCl}: \mathrm{Cl}^{-}$of $20,000 \mathrm{mg} / \mathrm{L}$ & 0.0246 & 0.0070 & 0.0032 & 0.04544 \\
& $\mathrm{NaCl}: \mathrm{Cl}^{-}$of $30,000 \mathrm{mg} / \mathrm{L}$ & 0.0222 & 0.0062 & 0.0019 & 0.03533 \\
\hline
\end{tabular}

TABLE 4: Mineralogical composition of these deep shales based on XRD analysis (\%).

\begin{tabular}{|c|c|c|c|c|c|c|c|c|c|c|}
\hline \multirow{2}{*}{ No. } & \multirow{2}{*}{ Quartz } & \multirow{2}{*}{ Feldspar } & \multirow{2}{*}{ Calcite } & \multirow{2}{*}{ Dolomite } & \multirow{2}{*}{ Pyrite } & \multirow{2}{*}{ Total clay } & \multicolumn{4}{|c|}{ Relative content of clay minerals } \\
\hline & & & & & & & Illite & Chlorite & Kaolinite & $I / S$ \\
\hline W1 & 43.7 & 3.1 & 3.3 & 2.5 & 1.4 & 46.0 & 53.0 & 12.0 & 7.0 & 28.0 \\
\hline W2 & 33.4 & 5.2 & 1.4 & 1.1 & 6.1 & 52.8 & 52.0 & 13.0 & 5.0 & 30.0 \\
\hline W3 & 49.1 & 2.7 & 4.4 & 4.1 & 2.8 & 36.9 & 62.0 & 13.0 & 5.0 & 20.0 \\
\hline W5 & 46.7 & 2.8 & 5.2 & 5.5 & 2.1 & 37.7 & 55.0 & 14.0 & 6.0 & 25.0 \\
\hline L6 & 50.0 & 2.8 & 5.8 & 5.5 & 2.3 & 33.6 & 50.0 & 15.0 & 5.0 & 30.0 \\
\hline L8 & 53.1 & 3.0 & 5.4 & 2.8 & 2.4 & 33.3 & 56.0 & 16.0 & 3.0 & 25.0 \\
\hline L9 & 56.0 & 3.6 & 2.0 & 2.4 & 2.3 & 33.7 & 67.0 & 13.0 & 0.0 & 20.0 \\
\hline L10 & 54.1 & 3.3 & 4.0 & 7.2 & 2.4 & 29.0 & 67.0 & 11.0 & 4.0 & 18.0 \\
\hline
\end{tabular}

TABle 5: Pore structure parameters of the deep shale samples.

\begin{tabular}{lccccc}
\hline No. & $\begin{array}{c}\text { Specific surface area } \\
\left(\mathrm{m}^{2} / \mathrm{g}\right)\end{array}$ & $\begin{array}{c}\text { Pore volume } \\
\left(\mathrm{cm}^{3} / \mathrm{g}\right)\end{array}$ & $\begin{array}{c}\text { Micropore volume } \\
\left(\mathrm{cm}^{3} / \mathrm{g}\right)\end{array}$ & $\begin{array}{c}\text { Mesopore volume } \\
\left(\mathrm{cm}^{3} / \mathrm{g}\right)\end{array}$ & $\begin{array}{c}\text { Macropore volume } \\
\left(\mathrm{cm}^{3} / \mathrm{g}\right)\end{array}$ \\
\hline W1 & 18.4568 & 0.025712 & 0.004242 & 0.010381 & 0.011089 \\
W2 & 16.4318 & 0.012139 & 0.003767 & 0.007610 & 0.000762 \\
W3 & 25.0481 & 0.029543 & 0.006281 & 0.013266 & 0.009996 \\
W5 & 25.3169 & 0.020872 & - & 0.020137 & 0.000735 \\
L6 & 20.5497 & 0.012404 & 0.005311 & 0.006599 & 0.000494 \\
L8 & 14.7216 & 0.009976 & 0.003499 & 0.005904 & 0.000573 \\
L9 & 27.2875 & 0.016899 & 0.007120 & 0.009107 & 0.000672 \\
L10 & 19.6068 & 0.012800 & 0.004978 & 0.007146 & 0.000676 \\
\hline
\end{tabular}

pore connectivity, the slope of the square root curve of cumulative spontaneous imbibition height $(H)$ and time in the logarithmic-logarithmic graph is generally 0.5 . However, due to the complexity of the shale pore structure, the cumulative imbibition height of shale deviates significantly from Handy's model [31]. Shale samples with poor pore connectivity have a curve slope of approximately 0.26 , while those with moderate pore connectivity have a curve slope of $0.26-0.5[31,32]$. The abnormal characteristics of shale are caused by the intensive heterogeneity of the pore network, poor connectivity, and the existence of clay. Yang et al. [33] proposed a new method to evaluate the imbibition capacity of shale reservoirs, which defined the ratio of imbibition volume and volume of rock sample as the spontaneous imbibition capacity of rock and effectively eliminated the influence of the size and shape of shale rock on the imbibition characteristics. The slope of the curve is the spontaneous imbibition rate, and the peak value is the spontaneous imbibition capacity. The model can be expressed as follows:

$$
\frac{V_{\mathrm{Imb}}}{A_{c} L}=\left[\frac{2 p_{e} \varphi\left(S_{w f}-S_{w i}\right)}{\left(\left(\mu_{g} / k_{g}\right)+\left(\mu_{w} / k_{w}\right)\right)}\right]^{1 / 2}\left(\frac{t}{L^{2}}\right)^{1 / 2},
$$

where $L$ is the core length, $\mathrm{cm} ; A_{c}$ is the cross-sectional area of water imbibition, $\mathrm{cm}^{2} ; S_{w f}$ is the water saturation of the leading edge, \%; $V_{\text {Imb }}$ is the volume of the inhaled liquid, $\mathrm{cm}^{3} ; p_{e}$ is the capillary force, $\mathrm{Pa} ; \varphi$ is the porosity, fraction, $S_{w i}$ is the initial water saturation, $\% ; \mu_{g}$ and $\mu_{w}$ are the viscosity of gas and water, respectively, Pa.s; and $k_{g}$ and $k_{w}$ are the permeability of gas and water, respectively, $\mathrm{mD}$.

In the process of shale spontaneous imbibition, the lowfield NMR technology can be used to monitor the distribution characteristics of the fluid in real time. The transverse relaxation time (T2) spectrum of NMR is widely used in the laboratory and logging fields [34-36]. The formula of 


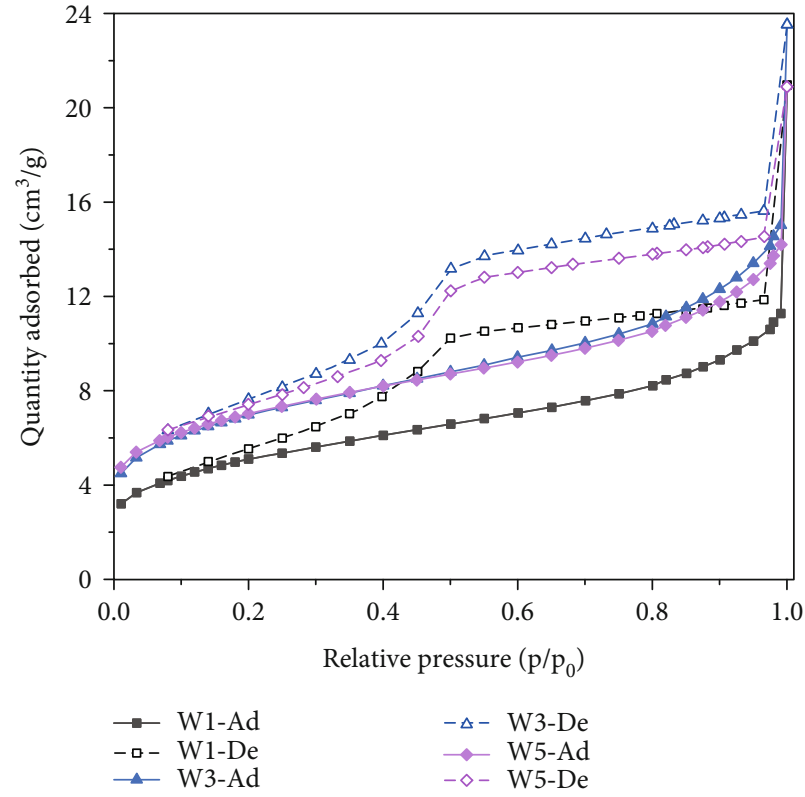

(a) Samples W1, W3, and W5

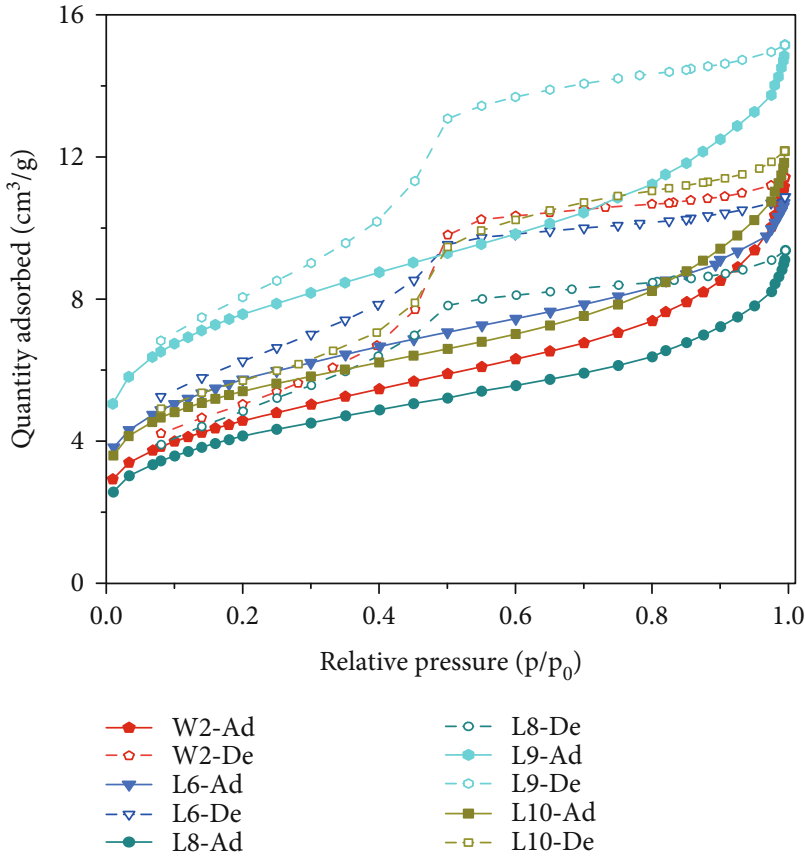

(b) Samples W2, L6, L8 L9, and L10

FIGURE 2: Low-temperature nitrogen adsorption isotherm curves of the deep Longmaxi Formation shale.

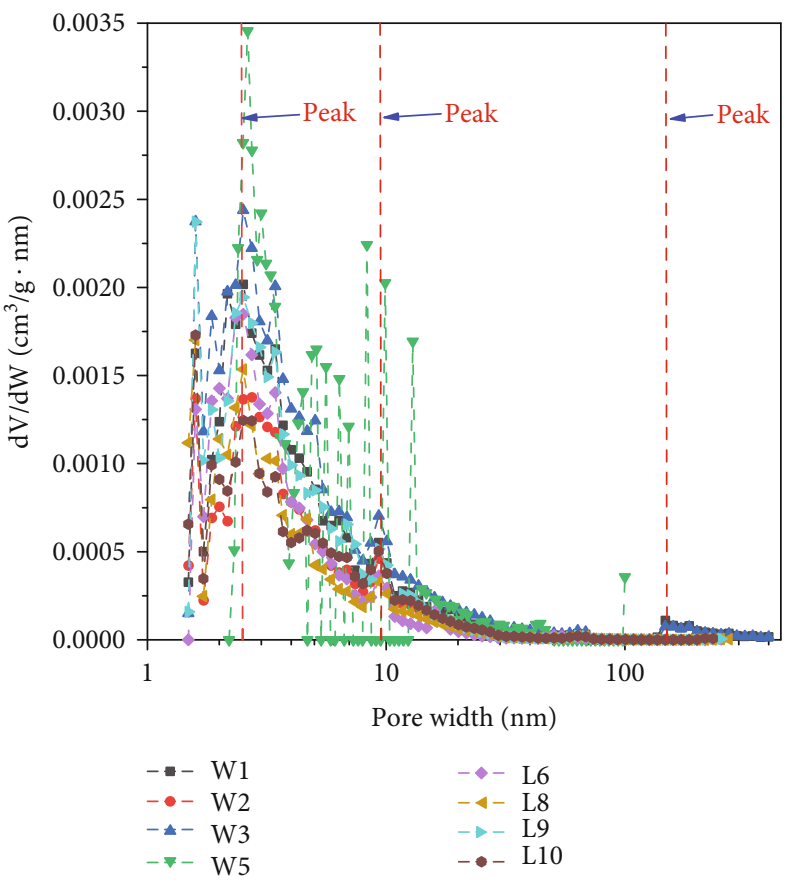

(a) Pore size distribution curves

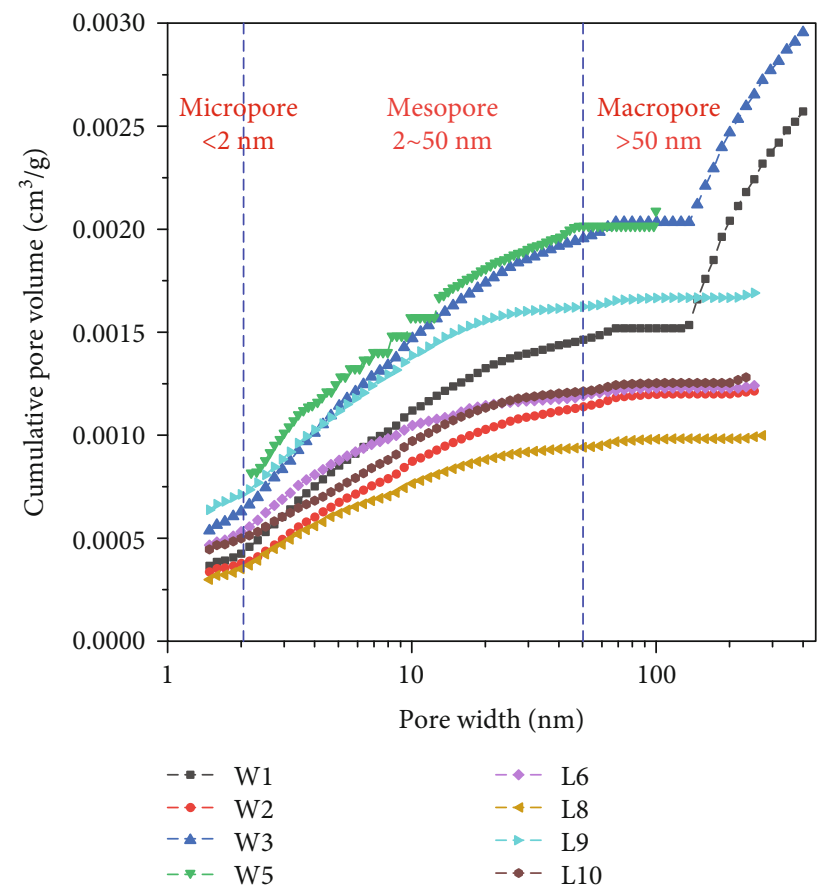

(b) Pore volume accumulation curves

FIgURE 3: Pore structure characteristics of the deep Longmaxi Formation deep shale.

lateral relaxation time $\mathrm{T} 2$ of fluid in pores can be expressed as follows:

$$
\frac{1}{T_{2}}=\frac{1}{T_{2 S}}+\frac{1}{T_{2 D}}+\frac{1}{T_{2 B}},
$$

where $T_{2 B}$ is the bulk relaxation time, $T_{2 S}$ is the surface relaxation time, and $T_{2 D}$ is the diffusion relaxation time.

For the $\mathrm{T} 2$ relaxation time of rock, the volume relaxation and diffusion relaxation times are usually ignored and simplified as 


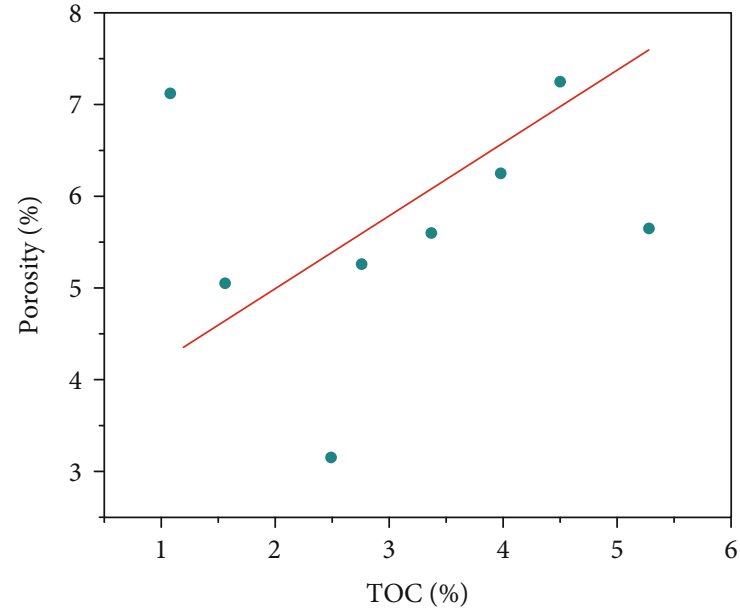

FIGURE 4: Relationship between porosity and TOC of the deep Longmaxi Formation shale samples.

$$
\frac{1}{T_{2}}=\frac{1}{T_{2 S}},
$$

The surface relaxation time $T_{2 S}$ is related to the pore volume and pore surface area, and its formula can be written as

$$
\frac{1}{T_{2 S}}=\rho_{2} \frac{S}{V},
$$

where $\rho_{2}$ is the transverse surface relaxation rate of the sample, $\mathrm{m} / \mathrm{s} ; S$ is the pore surface area, $\mathrm{m}^{2}$; and $V$ is the pore volume, $\mathrm{m}^{3}$.

Assuming the pore is tubular, the relationship between $\mathrm{T} 2$ and pore radius can be expressed as

$$
\frac{1}{T_{2}}=\rho_{2} \frac{1}{r}
$$

Therefore, the transverse relaxation time (T2) spectrum of the NMR reflects the characteristics of pore size distribution, and the $\mathrm{T} 2$ value is positively correlated with the pore radius $\mathrm{R}$. The $\mathrm{T} 2$ relaxation time of the fluid in the large pore is longer, and the T2 relaxation time of the fluid in the small pore is shorter. In addition, the more fluid in the pores, the greater the signal amplitude.

\section{Results}

4.1. Characterization of Shale Properties. The burial depth of these deep Longmaxi Formation shales of the southern Sichuan Basin, China, is over $3500 \mathrm{~m}$, where the maturity of the gas shale reaches the overmature stage. The measured characteristics and mineralogical composition of the deep Longmaxi Formation shales in this study are shown in Tables 1 and 4 . As seen from these results, the TOC content values range from $1.08 \%$ to $5.28 \%$, with an average of $3.13 \%$. The mineral composition is dominated by quartz and clay minerals, and the quartz content varies between $33.4 \%$ and $56.0 \%$, with an average of $48.89 \%$. The content of clay ranges from $29.0 \%$ to $52.8 \%$, with an average of $37.9 \%$, mainly illite,

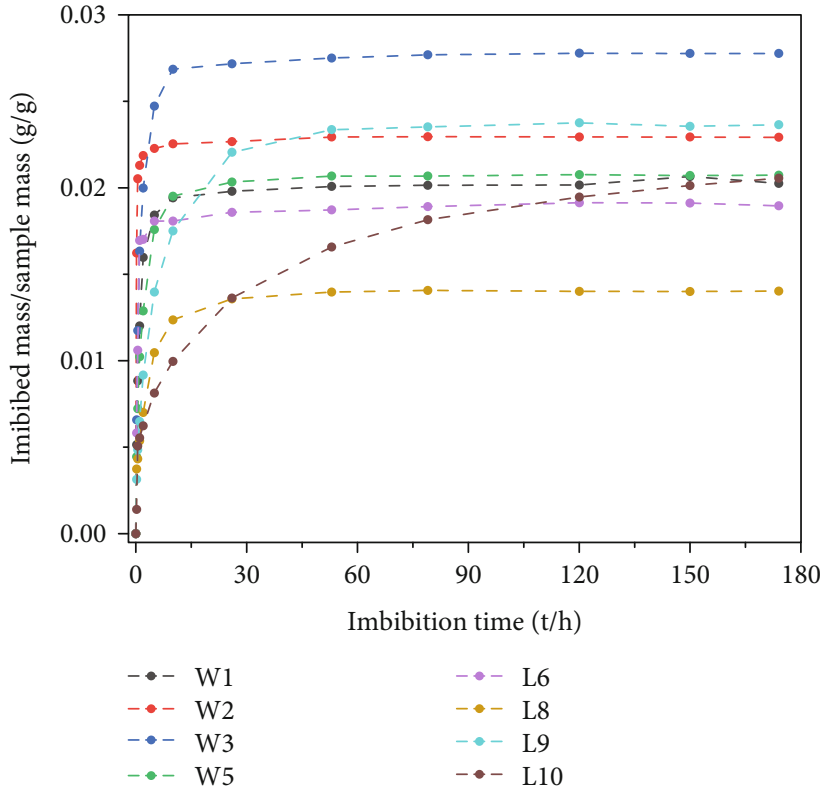

FIgURE 5: The imbibition proportion versus $t$ of the deep Longmaxi Formation shale samples in $\mathrm{NaCl}$ solution with a salinity of $\mathrm{Cl}^{-}$of $15,000 \mathrm{mg} / \mathrm{L}$.

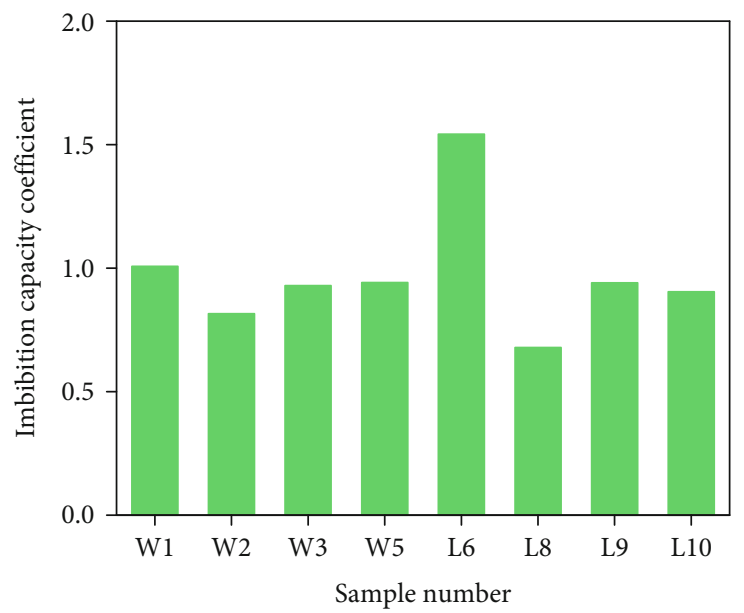

FIgURE 6: Imbibition capacity coefficient of different deep shale samples.

with fewer minerals such as illite/smectite mixed layers. The pore structure parameters are shown in Table 5. The DFT pore volumes of absorbed nitrogen vary between $9.98 \times 10^{-3} \mathrm{~cm}^{3} / \mathrm{g}$ and $2.95 \times 10^{-2} \mathrm{~cm}^{3} / \mathrm{g}$, and the BET-specific surface area values range from $14.72 \mathrm{~m}^{2} / \mathrm{g}$ in sample $\mathrm{L} 8$ to $27.29 \mathrm{~m}^{2} / \mathrm{g}$ in sample L9.

As shown in Figure 2, during the low-temperature nitrogen adsorption process, the shale samples undergo the capillary condensation. The low-temperature nitrogen adsorption and desorption curves form a hysteresis loop, and the shape of the hysteresis loop can reflect the pore shape [37]. In this study, the hysteresis loops of lowtemperature nitrogen adsorption and desorption curves of shale samples are similar to those of $\mathrm{H} 2$ (a)- and H2(b)-type hysteresis loops recommended by the International Union of 


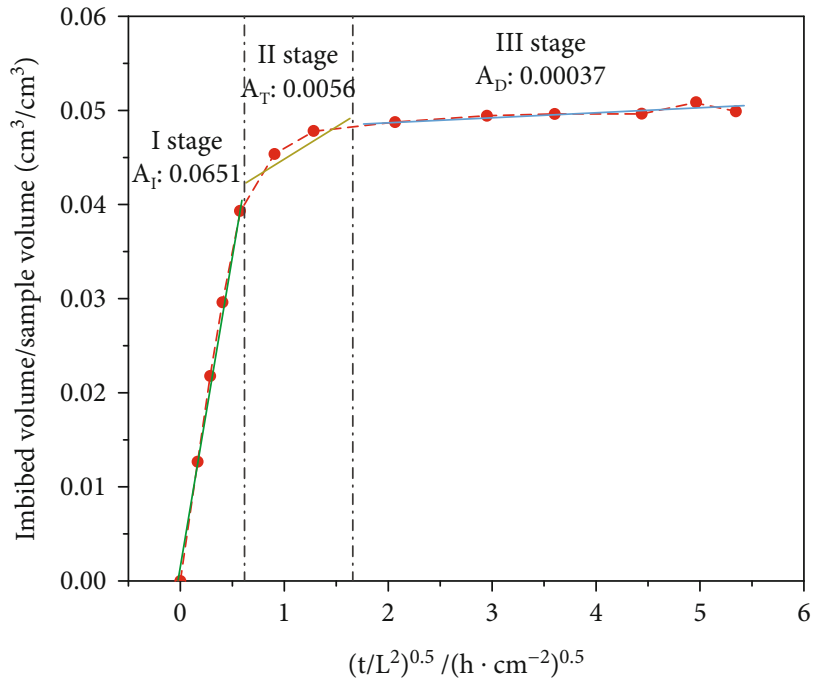

$-\bullet \mathrm{W} 1$

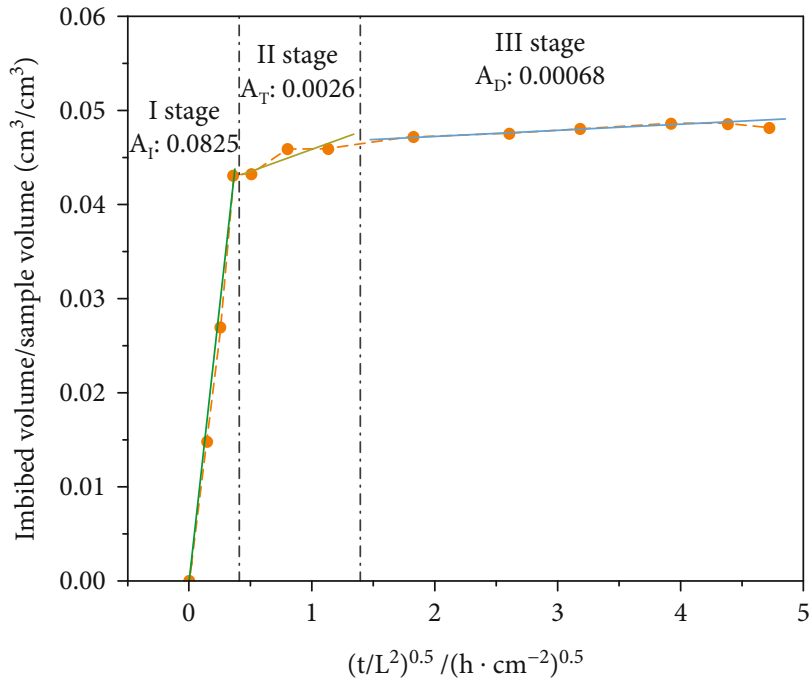

$-\bullet$ L6

(a) Sample W1

(b) Sample L6

FIgURE 7: The typically shale imbibed volume/sample volume versus $\sqrt{t / L^{2}}$ in $\mathrm{NaCl}$ solution with a salinity of $\mathrm{Cl}^{-}$of $15,000 \mathrm{mg} / \mathrm{L}$.

Pure and Applied Chemistry (IUPAC) and have the characteristics of H3-type hysteresis loops. The results indicate that the deep shale of the Longmaxi Formation has inkbottle pores with narrow pore throats and large pore bodies, parallel plate fracture pores, and wedge $V$-shaped pores. There are also some cylindrical pores and microcracks open at both ends. Inkbottle pores are mostly intergranular, developed in brittle minerals such as quartz and calcite, and parallel plate-shaped fractures or wedge $V$-shaped pores are mainly related to interlayer pores and microfractures of clay minerals [37].

As shown in Figure 3(a), samples W2, L6, L8, L9, and L10 have two obvious peaks at $2 \mathrm{~nm}$ and $10 \mathrm{~nm}$. However, for the W1, W3, and W5 samples, there are three peaks at $2 \mathrm{~nm}, 10 \mathrm{~nm}$, and $150 \mathrm{~nm}$, indicating that those pore structure characteristics are more complex than those of the other samples. Similarly, the cumulative pore volume curve of shale pore size in Figure 3(b) demonstrates that the pore volume of samples W1, W3, and W5 is larger than $0.02 \mathrm{~cm}^{3} / \mathrm{g}$, and the macropores are relatively enlarged. Micropores and mesopores are mainly dominant in the other samples, and the volume of macropores is lower. Figure 4 reveals that the porosity of shale samples has a certain positive correlation with TOC content, which implies that TOC content is a key effect on porosity.

4.2. Spontaneous Imbibition Characteristics of Shale. In this study, the shale samples were put into $\mathrm{NaCl}$ solution with a salinity of $\mathrm{Cl}^{-}$of $15,000 \mathrm{mg} / \mathrm{L}$, and the experimental results are shown in Figure 5. The spontaneous imbibition curves of different shale samples have similar overall characteristics; that is, the imbibition proportion (imbibed mass/sample mass) increases over time until reaching the equilibrium. The imbibition proportion of shale changes over time, namely, the imbibition proportion in the initial stage increases rapidly over time, and then the rising speed slowly decreases to zero. Different shale samples have different imbibition proportions, which are mainly determined by the mineral composition and pore structure characteristics of the shale itself.

When aqueous solutions are injected into organic-rich shales, the charged regions of the clay imbibe water molecules through the interlayer space of the clay. The imbibition volumes of some samples may be larger than the originally measured pore volumes due to the semipermeable membrane characteristic of the clay [38, 39]. Yang et al. [39] found that the imbibition volume of some shale samples could reach $400 \%$ of the measured pore volume. The maximum imbibition capacity of the shale matrix can be used to estimate the volume of fracturing fluid and evaluate the severity of water blockage [39]. The imbibition capacity coefficient is defined as the ratio between the total imbibition volume and pore volume [14], and the formula is as follows:

$$
R=\frac{M_{\mathrm{Imb}}}{\rho V \varnothing}
$$

where $R$ is the imbibition capacity coefficient, $M_{\operatorname{Imb}}$ is the final imbibition mass, $\mathrm{g}, \rho$ is the imbibition liquid density, $\mathrm{g} / \mathrm{cm}^{3}$, $V$ is the rock volume, $\mathrm{cm}^{3}$, and $\varnothing$ is the rock porosity, $\%$.

Figure 6 shows that the imbibition capacity coefficient of deep shale in Weiyuan and Luzhou are approximately 1, which is lower than that of shallow shale [39]. The reason is that the clay minerals in the Longmaxi Formation deep shale are mainly illite and contain fewer clay minerals such as illite/smectite mixed layers $[40,41]$. Similar to shallow shale, deep shale with a high illite content has an insufficient diffusion capacity; thus, water molecules are likely to induce water blocks $[16,42]$. Therefore, attention should be given to reducing the amount of injected fracturing fluid in the process of deep shale fracturing. 


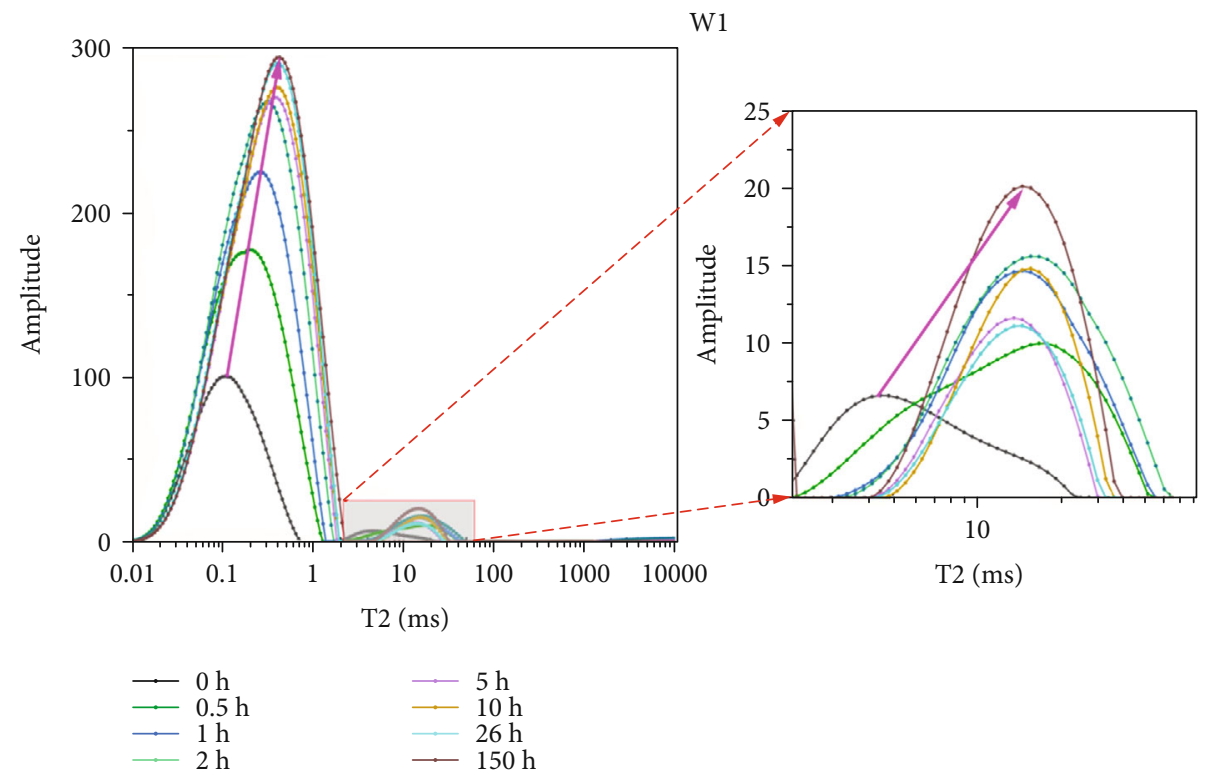

(a) NMR T2 spectrum distribution of sample W1

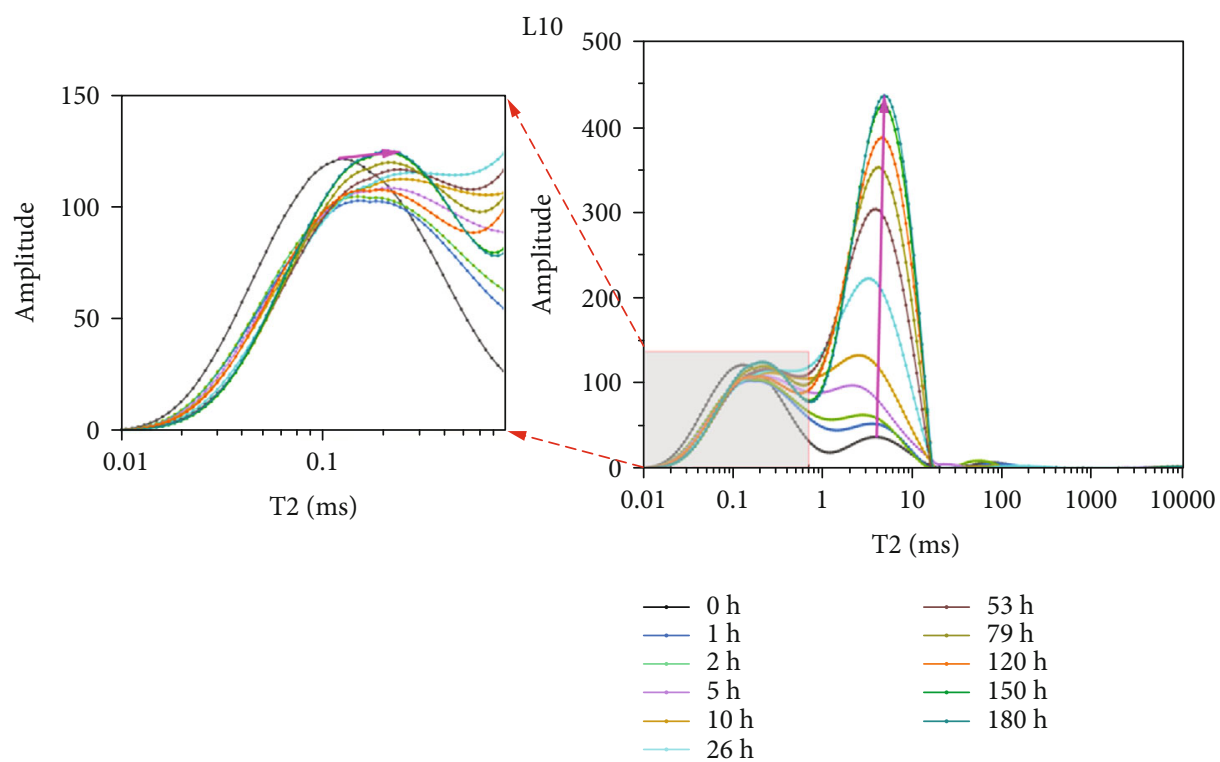

(b) NMR T2 spectrum distribution of sample L10

FIGURE 8: NMR T2 spectrum distribution of the deep shale during spontaneous imbibition.

4.3. Characteristics of Imbibition Curve of Shale. According to the experimental data of spontaneous imbibition in shale samples, the model proposed by Yang et al. [33] can be used to obtain the relationship between $V_{\mathrm{Imb}} / A_{c} L-\sqrt{t / L^{2}}$, as shown in Figure 7. The peak value of the curve represents the imbibition capacity of the shale, and the slope represents the imbibition rate. The spontaneous imbibition curve of shale is clearly divided into three sections: the initial spontaneous imbibition stage I, the intermediate transition stage II, and the late diffusion stage III. In the initial spontaneous imbibition stage, the imbibition volume increases rapidly with increasing time. The liquid is inhaled and filled with the main connected inorganic pores and microfractures under the action of capillary force and chemical osmotic

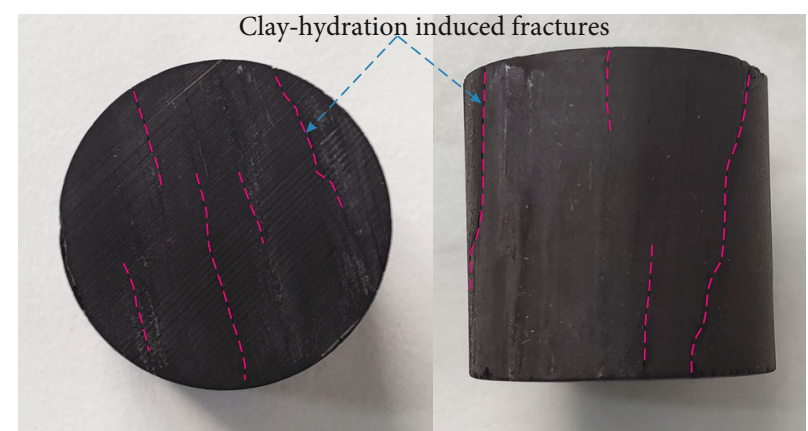

FIgUre 9: Clay hydration-induced fractures of the deep shale during imbibition. 


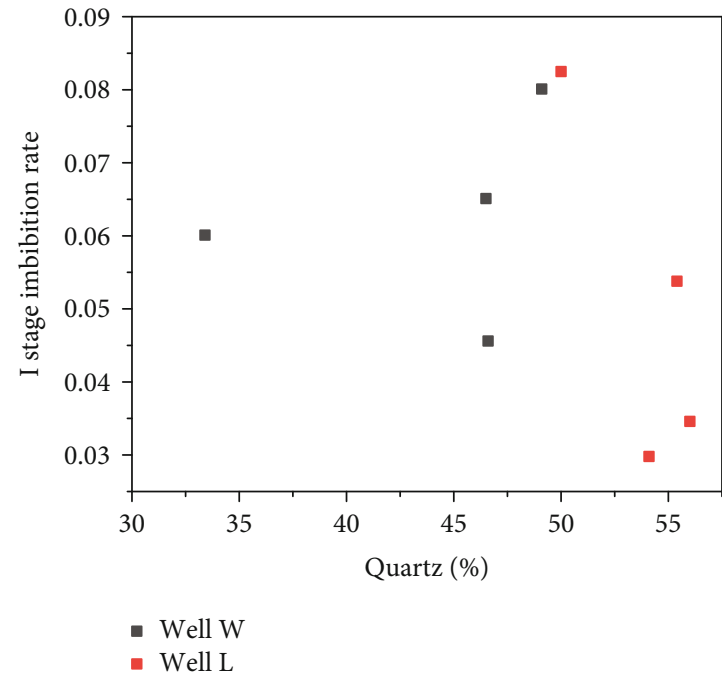

(a) Stage I spontaneous imbibition rate versus quartz content

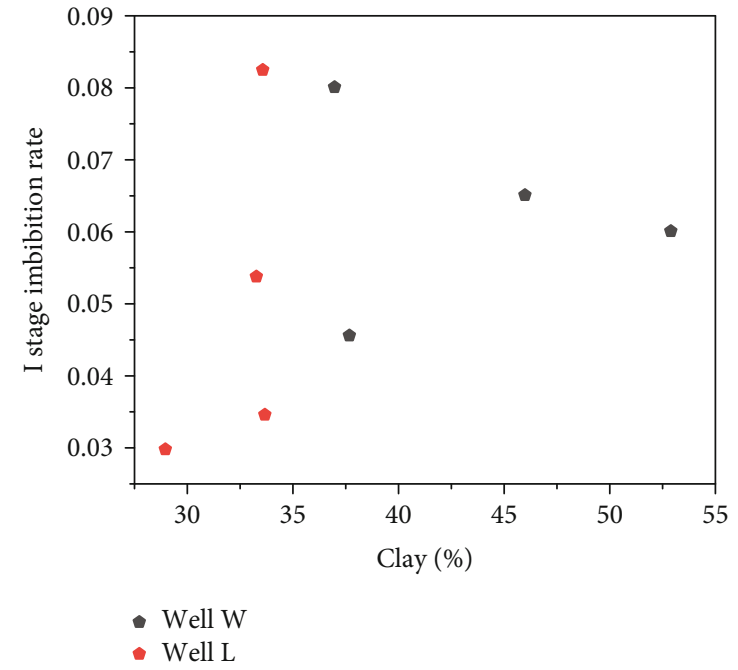

(b) Stage I spontaneous imbibition rate versus clay content

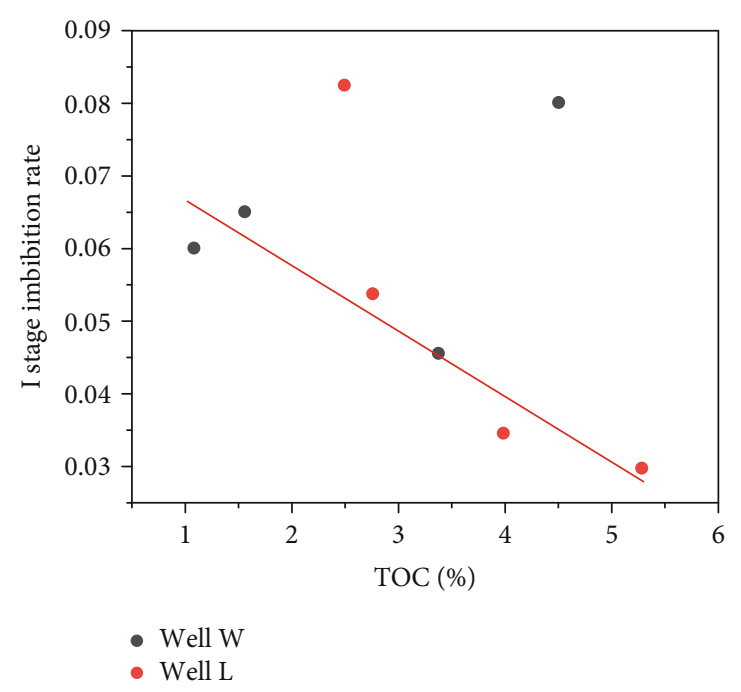

(c) Stage I spontaneous imbibition rate versus TOC content

Figure 10: Relationship between spontaneous imbibition rate and mineral composition and TOC content of the deep shale.

pressure, and the imbibition rate is relatively high. The second part is the intermediate transition stage. As the water saturation increases, the capillary force is greatly reduced, and the imbibed volume of microcracks and inorganic pores decreases. Thus, the imbibition rate gradually slows down. The imbibition rate is ultralow in the late diffusion stage. The liquid sucked into the macropores diffuses into the finer nanomatrix pores under the action of capillary force and then enters the clay particles under the action of chemical osmotic pressure.

The model proposed by Yang et al. [33] is used to fit the spontaneous imbibition curve in Figure 7, and the spontaneous imbibition parameters obtained are listed in Table 2 . The spontaneous imbibition rate and capacity of different shale samples are quite different and are determined by the mineral composition and pore structure of the shale reservoirs, which will be discussed and analyzed in the following section.
4.4. T2 Spectral Characteristics during Shale Imbibition. The NMR T2 spectra revealed the distribution characteristics of the fluid in shale and reflected the pore structure characteristics. Figure 8 demonstrates the variation in T2 spectra of different shale samples during imbibition. The T2 spectra of samples W2, W3, W5, L6, L8, and L9 have similar overall characteristics as sample W1. There are two peaks (the left peak area is much larger than the right peak area) in Figure $8(\mathrm{a})$, the left peaks range from $0.1 \mathrm{~ms}$ to $1 \mathrm{~ms}$, and the right peaks vary between $10 \mathrm{~ms}$ and $20 \mathrm{~ms}$, which indicates that these mainly contain micropores. In Figure 8(b), the left peak of sample L10 ranges from $0.1 \mathrm{~ms}$ to $1 \mathrm{~ms}$, and the right peak varies from $3 \mathrm{~ms}$ to $6 \mathrm{~ms}$. However, the T2 spectrum of sample L10 is different from that of sample $\mathrm{W} 1$, and the right peak is dominant, indicating that mesopores are the majority in sample L10. With increasing imbibition time, more fluid enters the pores under the capillary force and the osmotic pressure of the clay semipermeable 


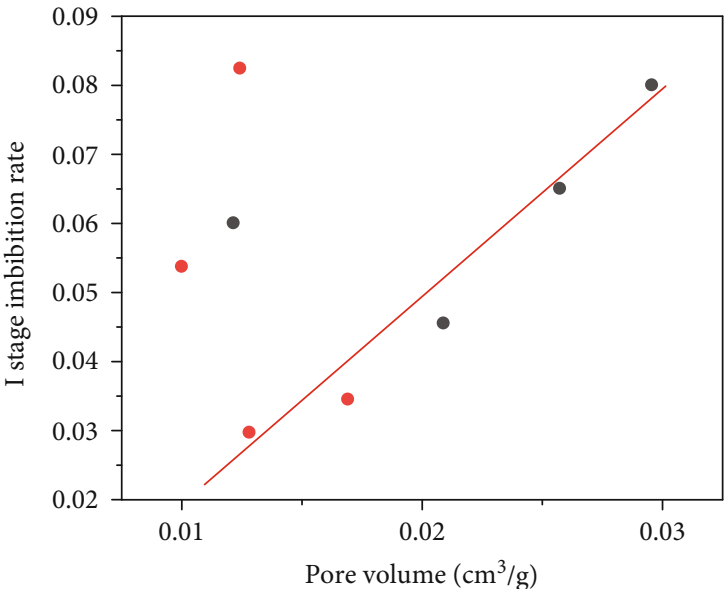

- Well W

- Well L

(a) Spontaneous imbibition rate versus pore volume

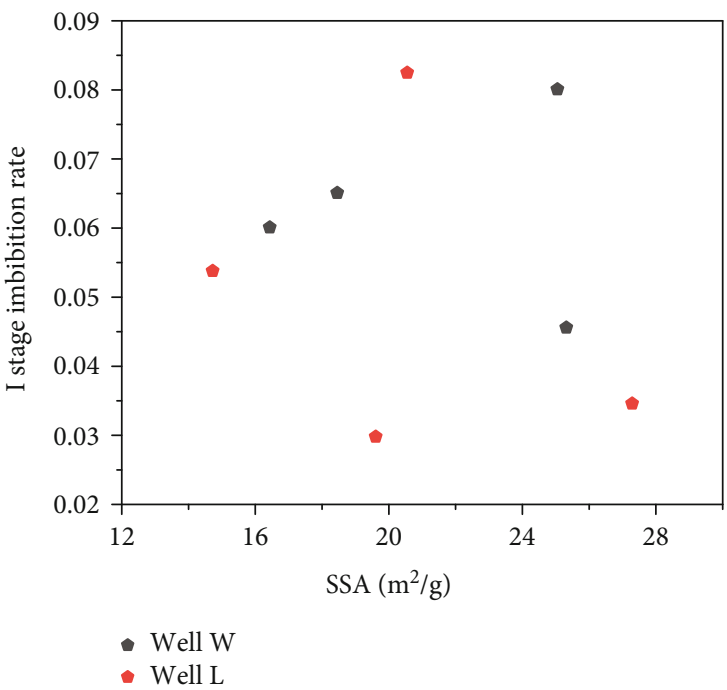

(c) Spontaneous imbibition rate versus SSA

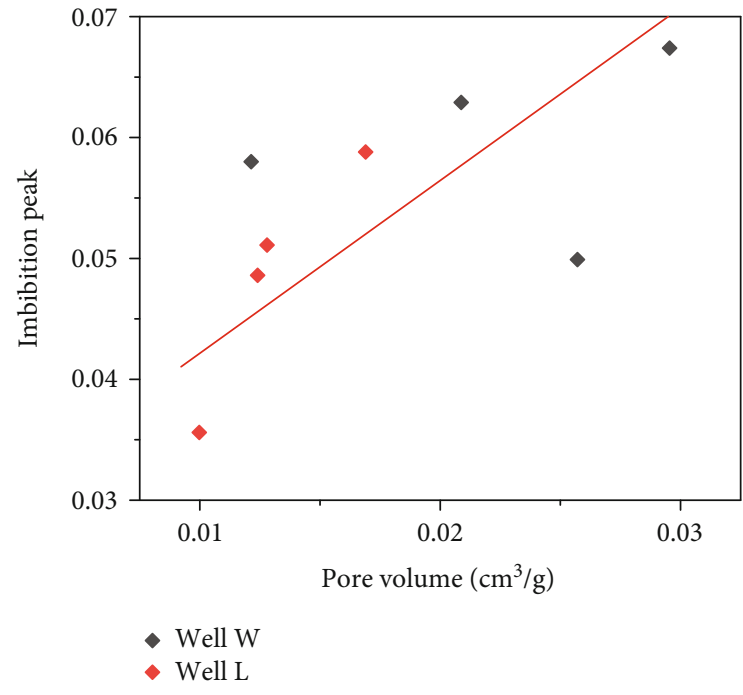

(b) Spontaneous imbibition peak value versus pore volume

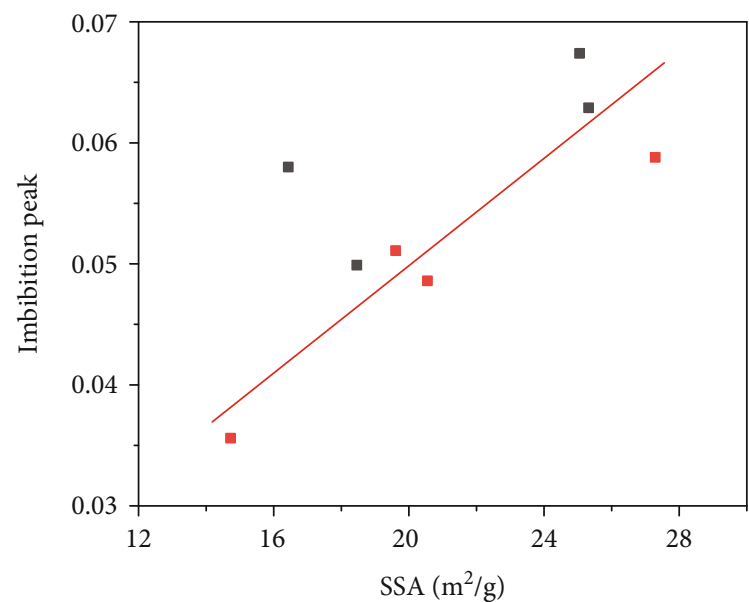

- Well W

- Well L

(d) Spontaneous imbibition peak value versus SSA

FIGURE 11: Relationship between spontaneous imbibition rate/imbibition capacity and pore structure of the deep shale.

membrane, the left and right peaks of the sample T2 spectrum gradually move to the upper right, and the right and lower ends of the left and right peaks also move to the right, indicating the occurrence of new pores and fractures [13, 35]. Meanwhile, the microcracks on the surface of shale samples were also found to increase gradually during the experiment in Figure 9. However, the T2 spectrum shows that the right end of the right peak moved to the right first and then to the left, indicating that the clay continued to swell as the imbibition volume and time increased, leading to the closure of some microcracks.

Deep shale with a high illite content has an insufficient diffusion capacity and is not prone to hydration and thus has limited room for pore structure improvement. Deep shale reservoirs have an optimal hydration time when their physical properties are the best, and shale with a high illite content has a shorter optimal hydration time [16]. Thus, attention should be given to controlling the amount of frac- turing fluid and the soaking time during the fracturing process of the Longmaxi Formation deep shale reservoirs.

\section{Discussion}

5.1. The Effects of Mineral Composition and TOC Content on Imbibition Characteristics. The quartz and clay mineral composition of the Longmaxi Formation deep shale accounted for $83.1 \% \sim 92.5 \%$ of the total mineral composition. Therefore, the effect of quartz and clay on the spontaneous imbibition experiments is mainly investigated in this study. Figures 10(a) and 10(b) demonstrate that the imbibition rates of stage I in well $\mathrm{W}$ and well $\mathrm{L}$ are almost irrelevant with the clay and quartz contents. That means the correlation between the imbibition rates of stage I and clay minerals and quartz needs further research. However, Figure 10(c) reveals that as the TOC content increases, the imbibition rate decreases. The reason is that the 


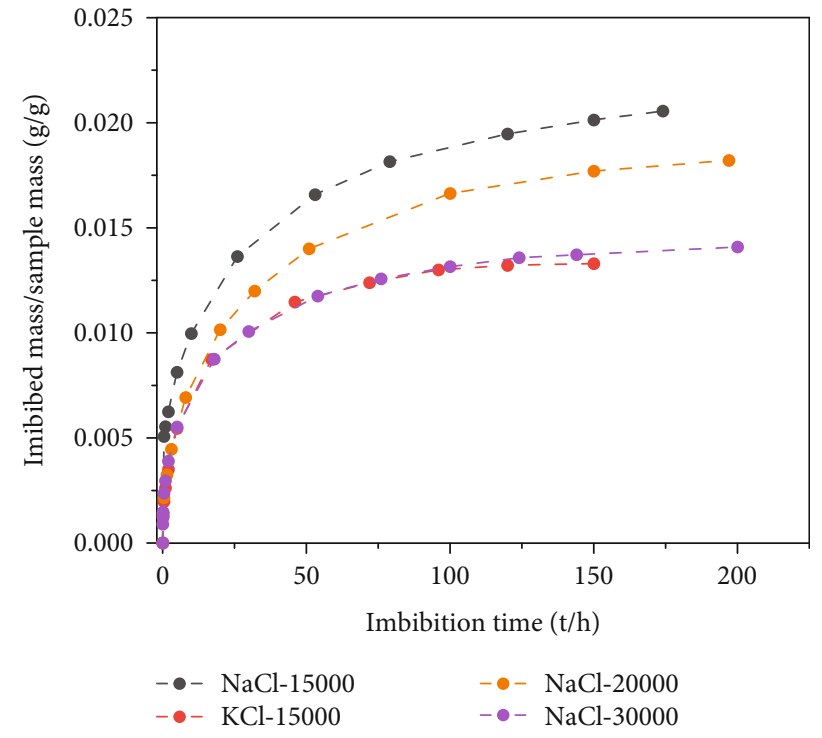

(a) Imbibition proportion versus $t$

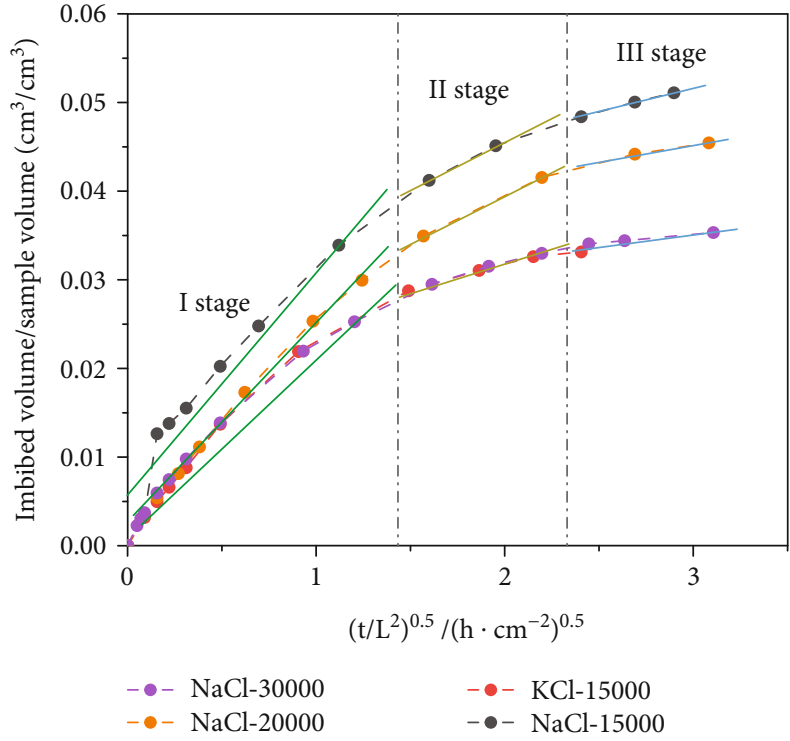

(b) Imbibed volume/sample volume versus $\sqrt{t / L^{2}}$

FIGURE 12: Imbibition characteristic curve of the deep shale samples in different salt solutions.

fundamental controlling factor of wettability is mineral composition and functional group, and marine shale of the Longmaxi Formation with the higher TOC content has a stronger water-repellant property $[43,44]$; so, the higher TOC content would weaken the water imbibition rate.

\subsection{The Effect of Pore Structure on Imbibition} Characteristics. Low-temperature nitrogen adsorption results show that the pore structures of the shale samples are different, which may lead to different fluid imbibition characteristics. Thus, the relationship between shale pore structure and imbibition rate and imbibition capacity is investigated in this study, and the results are shown in Figure 11. Figures 11(a) and 11(b) demonstrate that the shale spontaneous imbibition rates and imbibition capacities in well $\mathrm{W}$ and well $\mathrm{L}$ have a certain positive correlation with the pore volume, indicating that the connectivity of the pore network improves with increasing pore volume. However, in Figure 11(c), there is no obvious correlation between the imbibition rate and the specific surface area (SSA). The imbibition capacity has a certain positive correlation with the specific surface area in Figure 11(d), namely, the imbibition capacity also increases with increasing specific surface area.

5.3. The Effect of Inorganic Salt Solution on Imbibition. Inorganic cations can inhibit the imbibition capacity of shale to a certain extent. It can be concluded from Figure 12 and Table 3 that the type and salinity of inorganic salt solution have a significant effect on the imbibition rate and imbibition capacity of shale. The higher the salinity of the $\mathrm{NaCl}$ solution is, the lower the spontaneous imbibition rate and imbibition capacity of shale. In addition, under the same salinity, the spontaneous imbibition rate and imbibition capacity of shale in $\mathrm{KCl}$ solution are both lower than those in $\mathrm{NaCl}$ solution, indicating that the imbibition inhibition effect of $\mathrm{K}^{+}$on shale is greater than that of $\mathrm{Na}^{+}$. The mechanism is that the hydration energy of $\mathrm{K}^{+}$is lower, and the electrostatic attraction between the clay cell crystal layer and $\mathrm{K}^{+}$is larger; so, the dispersion inhibition of clay is stronger. On the other hand, $\mathrm{Na}^{+}$has a high hydration energy, and the electrostatic attraction between the clay cell crystal layer and $\mathrm{Na}^{+}$is smaller, and thus its inhibition effect on the hydration and expansion of clay is low [45]. Consequently, to suppress shale hydration, fluids with a high $\mathrm{K}^{+}$ content can be injected into the Longmaxi Formation deep shale.

\section{Conclusions}

In this study, the petrophysical properties of deep shales were measured in the Longmaxi Formation of the southern Sichuan Basin, China, and the spontaneous imbibition and T2 spectral characteristics of deep shales were evaluated with high-precision electronic balance and low-field nuclear magnetic resonance. Moreover, the effects of mineral composition, TOC content, pore structure, and inorganic salt solution on imbibition were discussed. According to the above results, the main conclusions from this study are summarized as follows:

(1) The Longmaxi Formation deep shale in southern Sichuan is generally rich in organic matter, with an average TOC content of $3.13 \%$. Quartz is the main mineral in deep shale, with an average content of $48.89 \%$, followed by clay, with an average content of $37.9 \%$, which is mainly illite, with fewer minerals such as illite/smectite mixed layers. Micropores $(<2 \mathrm{~nm})$ and mesopores $(2 \sim 50 \mathrm{~nm})$ are the main pores, and TOC content is a key effect on porosity of the deep Longmaxi Formation shale. 
(2) The variation in the T2 spectra with imbibition time demonstrates that clay hydration and swelling produce new pores and microcracks, but with increasing imbibition volume and time, some pores and microcracks close again. The deep Longmaxi Formation shale, with a high illite content, is not prone to hydration and thus has limited room for pore structure improvement. Shale with a high illite content has a shorter optimal hydration time. Therefore, attention should be given to determining the amount of fracturing fluid and the soaking time during the fracturing process of the Longmaxi Formation deep shale.

(3) The imbibition capacity of deep shale is determined by the mineral composition, pore structure, and inorganic salt solution. The Longmaxi Formation deep shale contains fewer clay minerals such as illite/smectite mixed layer, and its imbibition capacity coefficient is lower than that of shallow shale. Higher TOC content would weaken the water imbibition rate of the deep Longmaxi Formation shale. The inorganic salt solution has an inhibitory effect on the imbibition of shale. The inhibitory effect of $\mathrm{K}^{+}$ on the imbibition of shale is greater than that of $\mathrm{Na}^{+}$at the same salinity, and the higher salinity will have a stronger inhibitory effect. Consequently, to suppress shale hydration, fluids with a high $\mathrm{K}^{+}$content can be injected into the Longmaxi Formation deep shale.

\section{Data Availability}

The data used to support the findings of this study are available from the first author upon request.

\section{Conflicts of Interest}

The authors declare that there are no conflicts of interest regarding the publication of this paper.

\section{Acknowledgments}

This work is financially supported by the project of the National Natural Science Foundation of China (Nos. 1217021033, 11802312, and U1762216).

\section{References}

[1] X. Ma, X. Li, F. Liang et al., "Dominating factors on well productivity and development strategies optimization in Weiyuan shale gas play, Sichuan Basin, SW China," Petroleum Exploration and Development, vol. 47, no. 3, pp. 594-602, 2020.

[2] W. J. Shen, X. Z. Li, T. R. Ma, J. Cai, X. Lu, and S. Zhou, "Highpressure methane adsorption behavior on deep shales: Experiments and modeling," Physics of Fluids, vol. 33, no. 6, article 063103, 2021.

[3] S. Q. Wang, "Shale gas exploitation: status, issues and prospects," Natural Gas Industry, vol. 37, no. 6, pp. 115-130, 2017.
[4] S. G. Liu, K. Jiao, J. C. Zhang et al., "Research progress on the pore characteristics of deep shale gas reservoirs: an example from the lower Paleozoic marine shale in the Sichuan Basin," Natural Gas Industry, vol. 41, no. 1, pp. 29-41, 2021.

[5] D. F. Du, Y. Z. Zhang, L. N. Zhang, X. Liu, and M. R. Xu, "Research progress and prospect of seepage mechanism in shale gas reservoirs," Unconventional Oil \& Gas, vol. 8, no. 3, pp. 1-9, 2021.

[6] W. J. Shen, X. Z. Li, A. Cihan, X. Lu, and X. Liu, "Experimental and numerical simulation of water adsorption and diffusion in shale gas reservoir rocks," Advances in Geo-Energy Research, vol. 3, no. 2, pp. 165-174, 2019.

[7] I. Vandecasteele, I. Marí Rivero, S. Sala et al., "Impact of shale gas development on water resources: a case study in northern Poland," Environmental Management, vol. 55, no. 6, pp. 1285-1299, 2015.

[8] H. Singh, "A critical review of water uptake by shales," Journal of Natural Gas Science and Engineering, vol. 34, pp. 751-766, 2016.

[9] D. O'Malley, S. Karra, R. P. Currier, N. Makedonska, J. D. Hyman, and H. S. Viswanathan, "Where does water go during hydraulic fracturing?," Groundwater, vol. 54, no. 4, pp. 488497, 2016.

[10] C. E. Neuzil and A. M. Provost, "Recent experimental data may point to a greater role for osmotic pressures in the subsurface," Water Resources Research, vol. 45, no. 3, pp. 450-455, 2009.

[11] W. J. Shen, X. Z. Li, X. B. Lu, W. Guo, S. Zhou, and Y. Wan, "Experimental study and isotherm models of water vapor adsorption in shale rocks," Journal of Natural Gas Science and Engineering, vol. 52, pp. 484-491, 2018.

[12] Y. P. Sun, B. J. Bai, and M. Z. Wei, "Microfracture and surfactant impact on linear cocurrent brine imbibition in gassaturated shale," Energy \& Fuels, vol. 29, no. 3, pp. 14381446, 2015.

[13] W. J. Shen, F. Q. Song, X. Hu, G. Zhu, and W. Zhu, "Experimental study on flow characteristics of gas transport in microand nanoscale pores," Scientific Reports, vol. 9, no. 1, article 10196, 2019.

[14] X. L. Yuan and C. Huang, "Research on back row characteristics of fuling shale gas field," Unconventional Oil \& Gas, vol. 4, no. 5, pp. 66-70, 2020.

[15] Y. H. Shen, H. K. Ge, S. Su, D. Q. Liu, Z. H. Yang, and J. R. Liu, "Imbibition characteristic of shale gas formation and waterblock removal capability," Scientia Sinica Physica, Mechanica \& Astronomica, vol. 47, no. 11, pp. 114609-114698, 2017.

[16] F. Zeng, Q. Zhang, J. Guo, B. Zeng, Y. Zhang, and S. He, "Mechanisms of shale hydration and water block removal," Petroleum Exploration and Development, vol. 48, no. 3, pp. 752-761, 2021.

[17] E. Ghanbari and H. Dehghanpour, "Impact of rock fabric on water imbibition and salt diffusion in gas shales," International Journal of Coal Geology, vol. 138, pp. 55-67, 2015.

[18] Z. Y. Gao and Q. H. Hu, "Pore structure and spontaneous imbibition characteristics of marine and continental shales in China," AAPG Bulletin, vol. 102, no. 10, pp. 1941-1961, 2018.

[19] R. Yang, Q. H. Hu, J. Z. Yi et al., "The effects of mineral composition, TOC content and pore structure on spontaneous imbibition in lower Jurassic Dongyuemiao shale reservoirs," Marine and Petroleum Geology, vol. 109, pp. 268-278, 2019. 
[20] X. Guo, Y. Li, T. Borjigen et al., "Hydrocarbon generation and storage mechanisms of deep-water shelf shales of Ordovician Wufeng Formation-Silurian Longmaxi Formation in Sichuan Basin, China," Petroleum Exploration and Development, vol. 47, no. 1, pp. 204-213, 2020.

[21] B. Roychaudhuri, T. T. Tsotsis, and K. Jessen, "An experimental investigation of spontaneous imbibition in gas shales," Journal of Petroleum Science and Engineering, vol. 111, pp. 87-97, 2013.

[22] B. Roychaudhuri, T. T. Tsotsis, and K. Jessen, "Shale-fluid interactions during forced lmbibition and flow-back," Journal of Petroleum Science and Engineering, vol. 172, pp. 443-453, 2019.

[23] Z. Zhou, B. Hoffman, D. Bearinger, and X. Li, "Experimental and numerical study on spontaneous imbibition of fracturing fluids in shale gas formation," in SPE/CSUR Unconventional Resources Conference, Calgary, Alberta, 2014.

[24] X. Ma, J. Xie, R. Yong, and Y. Zhu, "Geological characteristics and high production control factors of shale gas reservoirs in Silurian Longmaxi Formation, southern Sichuan Basin, SW China," Petroleum Exploration and Development, vol. 47, no. 5, pp. 901-915, 2020.

[25] M. M. Labani, R. Rezaee, A. Saeedi, and A. A. Hinai, "Evaluation of pore size spectrum of gas shale reservoirs using low pressure nitrogen adsorption, gas expansion and mercury porosimetry: a case study from the Perth and Canning Basins, Western Australia," Journal of Petroleum Science and Engineering, vol. 112, pp. 7-16, 2013.

[26] F. Yang, Z. F. Ning, S. D. Zhang, C. P. Hu, and L. H. Q. Du LH, "Characterization of pore structures in shales through nitrogen adsorption experiment," Nature Gas Industry, vol. 33, no. 4, pp. 135-140, 2013.

[27] X. H. Ma, W. J. Shen, X. Z. Li, Y. Hu, X. Liu, and X. Lu, “Experimental investigation on water adsorption and desorption isotherms of the Longmaxi shale in the Sichuan Basin, China," Scientific Reports, vol. 10, no. 1, article 13434, 2020.

[28] R. Lucas, "Ueber das Zeitgesetz des kapillaren Aufstiegs von Flüssigkeiten," Kolloid-Zeitschrift, vol. 23, no. 1, pp. 15-22, 1918.

[29] E. W. Washburn, "The dynamics of capillary flow," Physical Review, vol. 17, no. 3, pp. 273-283, 1921.

[30] L. L. Handy, "Determination of effective capillary pressures for porous media from imbibition data," Transactions of the AIME, vol. 219, no. 1, pp. 75-80, 1960.

[31] Q. H. Hu, R. P. Ewing, and S. Dultz, "Low pore connectivity in natural rock," Journal of Contaminant Hydrology, vol. 133, pp. 76-83, 2012.

[32] Q. H. Hu, R. P. Ewing, and H. D. Rowe, "Low nanopore connectivity limits gas production in Barnett formation," Journal of Geophysical Research: Solid Earth, vol. 120, no. 12, pp. 8073-8087, 2015.

[33] L. Yang, H. K. Ge, Y. H. Shen et al., "Experimental research on the shale imbibition characteristics and its relationship with microstructure and rock mineralogy," in SPE Asia Pacific Unconventional Resources Conference and Exhibition, Brisbane, Australia, 2015.

[34] P. F. Zhang, S. F. Lu, J. Q. Li, J. Zhang, H. Xue, and C. Chen, "Comparisons of SEM, low-field NMR, and mercury intrusion capillary pressure in characterization of the pore size distribution of lacustrine shale: a case study on the Dongying depression, Bohai Bay basin, China," Energy \& Fuels, vol. 31, no. 9, pp. 9232-9239, 2017.
[35] L. Yang, N. H. Dou, X. B. Lu et al., “Advances in understanding imbibition characteristics of shale using an NMR technique: a comparative study of marine and continental shale," Journal of Geophysics and Engineering, vol. 15, no. 4, pp. 1363-1375, 2018.

[36] J. Yang, J. Y. Leng, L. K. Qiao, L. L. Wang, and J. D. Ding, "Parameter prediction of water imbibition in unsaturated shales using the NMR method," Geofluids, vol. 2019, Article ID 4254159, 9 pages, 2019.

[37] S. B. Chen, Y. M. Zhu, H. Y. Wang, H. L. Liu, W. Wei, and J. H. Fang, "Structure characteristics and accumulation significance of nanopores in Longmaxi shale gas reservoir in the southern Sichuan Basin," Journal of China Coal Society, vol. 37, no. 3, pp. 438-444, 2012.

[38] H. K. Ge, L. Yang, Y. H. Shen et al., "Experimental investigation of shale imbibition capacity and the factors influencing loss of hydraulic fracturing fluids," Petroleum Science, vol. 12, no. 4, pp. 636-650, 2015.

[39] L. Yang, H. K. Ge, X. Shi et al., "The effect of microstructure and rock mineralogy on water imbibition characteristics in tight reservoirs," Journal of Natural Gas Science and Engineering, vol. 34, pp. 1461-1471, 2016.

[40] B. Thyberg, J. Jahren, T. Winje, K. Bjørlykke, J. I. Faleide, and Ø. Marcussen, "Quartz cementation in Late Cretaceous mudstones, northern North Sea: changes in rock properties due to dissolution of smectite and precipitation of micro- quartz crystals," Marine and Petroleum Geology, vol. 27, no. 8, pp. 1752-1764, 2010.

[41] G. Q. Luan, C. M. Dong, C. F. Ma, C. Y. Lin, J. Y. Zhang, and X. F. Lu, "Pyrolysis simulation experiment study on diagenesis and evolution of organic-rich shale," Acta Sedimentologica Sinica, vol. 34, no. 6, pp. 1208-1216, 2016.

[42] P. Li, J. Zhang, R. Rezaee et al., "Effect of adsorbed moisture on the pore size distribution of marine- continental transitional shales: insights from lithofacies differences and clay swelling," Applied Clay Science, vol. 201, article 105926, 2021.

[43] R. Yang, S. He, Q. H. Hu, G. Zhai, J. Yi, and L. Zhang, "Comparative investigations on wettability of typical marine, continental, and transitional shales in the Middle Yangtze Platform (China)," Energy \& Fuels, vol. 32, no. 12, pp. 12187-12197, 2018.

[44] P. Li, J. Zhang, R. Rezaee et al., "Effects of swelling-clay and surface roughness on the wettability of transitional shale," Journal of Petroleum Science and Engineering, vol. 196, article 108007, 2021.

[45] J. Xiong, S. S. Chen, L. X. Liang, Y. Y. Xiao, L. Shen, and L. P. Yang, "Imbibition characteristics and influencing factors of Longmaxi Formation shale," Journal of Guilin University of Technology, vol. 40, no. 4, pp. 688-694, 2020. 